\title{
Mongolian Female Rulers as Patrons of Tibetan Printing at the Yuan Court: Some Preliminary Observations on Recently Discovered Materials
}

\author{
Kawa Sherab Sangpo
}

$\mathbf{1}$

Introduction

For several years with my colleagues of the dPal brtsegs Research Institute I have been exploring libraries and repositories of books and manuscripts across Tibet, trying to restore collections and find neglected treasures of cultural heritage. Among the texts that I have discovered are several prints that were produced at the Yuan court during the 13th and 14th centuries and then apparently taken to Central Tibet. Many are unfortunately just fragments and loose folios; a few however are complete enough to give us precious information on their production. I have recently published articles (Kawa Sherab Sangpo 2013; 2009) discussing some of the most significant finds. In this brief note I shall highlight some of these texts as their print was sponsored by three Mongolian female rulers of the Yuan dynasty: Chabi, Kököchin and Bulughan (see also Rossabi 1979: 153-180; 1988). From this point of view these texts are important witnesses to the role played by Mongolian elite women in the promotion of Tibetan printing.

In the gNas bcu lha khang of 'Bras spungs monastery there is a printed copy of the Tshad ma rigs pa'i gter (Treasury of the Science of Valid Cognition) by Sa skya Pandita. According to the colophon, this print edition had been instigated by Khublai Khan's main consort, Empress Chabi (for a discussion of this print edition see also van der Kujip 1993: 280-283; 2014: 1-5; and Kawa Sherab Sangpo 2009; 2013). The colophon states:

This [print] was begun by dPon mo chen po Cha bu who bears the auspicious marks of family lineage and physical beauty, has devotion to the Dharma, is loving and economically well-endowed and an excellent

(C) KAWA SHERAB SANGPO, 2016 | DOI 10.1163/9789004316256_005

This is an open access chapter distributed under the terms of the Creative Commons Attribution-

Noncommercial 3.0. Unported (CC BY-NC 3.0) License. 
manager. It was completed to perfection by her royal prince's glorious consort Queen Go go cin who was a patron of religion, akin to a Mother to all sentient beings, immaculately blessed in respect of family lineage, physical beauty and educational accomplishments. Contemporaneously, too, may the King and the prince, the Queen and the entire family lineage enjoy good health and longevity; be blessed with abundance of religious merit, material and financial prosperity. Whosoever remembers, exhorts others, writes, prints or endeavours to provide the wherewithal for such [producing holy texts], may they all spontaneously attain both temporary and ultimate aspirations. May auspiciousness spread in all directions and at all times. In the year of the Wood Male Monkey, on the 8th [day] of the waxing moon period of the 12th month, [this print was] fully completed [i.e. December 16, 1284].

"dPon mo chen po Cha bu" is clearly Empress Chabi, the main wife of Kublai Khan and the mother of prince Se chen alias g.Yus tsung (Yu zong, 裕宗) (1243/5-1286) also known as Zhenjin and Jingim (mentioned in Marco Polo's travel account). In the year $1260 \mathrm{AD}$, when the Yuan dynasty was just established, she was enthroned as the Senior Queen, and passed away in $1281 \mathrm{AD}$ during the 18th throne year of Kre yon. In the year $1294 \mathrm{AD}$, during the 31st throne year of Kre yon, Emperor The mur (Temür Öljeytü) alias Khreng tsung ascended the throne, and she was awarded posthumously the royal award and title of "clever and beautiful queen” (Zhaorui Shunsheng Huanghou, 昭睿順圣皇后). ${ }^{1}$

Kököchin (alias Bo lan ye qie chi fei zi 伯蓝也怯赤妃子?)

It is not completely clear who is the queen referred to in the colophon of the 1284 print of the Tshad ma rigs gter as the "blue lady" (Go go cin, i.e. Kököchin). Go go cin, is claimed to be the queen of Prince g.Yus tsung (Yu zong, 裕宗), the son of Queen Cha bu (Chabi). Also known as Zhenjin he was the heir apparent of Khublai Khan. Documentary research and analysis reveals that Prince g.Yus tsung had two queens - one named Bo lan ye chas khre (Bo lan ye qie chi fei zi, 伯蓝也怯赤妃子) and the other named An kren mi'i hre (An zhen mi shi fei zi, 安真迷失妃子). However there is no evidence associating the name Go go cin with either of these two queens. Nevertheless, indicating that she was invested with the title of 'Senior Queen' and living a glorious life, this term must most probability refer to Queen Bo lan ye chas khre, because she was enthroned as

1 《元史・列传・后妃》卷一百一十四, 中华书局 1976 年版, 第 2871 页 


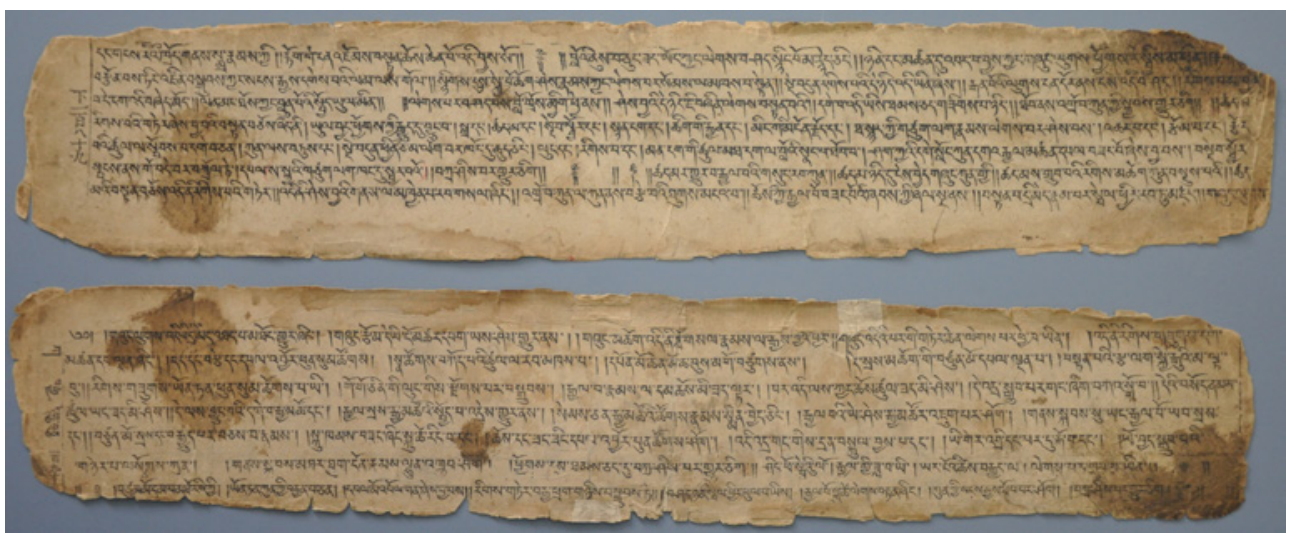

FIGURE 3.1 Colophon of the Tsad ma rigs gter print preserved at Tibet University Library. PHOTOGRAPH KAWA SHERAB SANGPO

the 'Senior Queen' in the year 1294 AD during the 31st throne-year of Kre yon, and passed away in the year $1300 \mathrm{AD}$ during the 4th throne-year of Twa Te, and this is consistent with the time frame of the events.

4

\section{Empress Bulughan ('Bol gan)}

The afore mentioned copy of Sa skya Pandita's Tshad ma rigs gter preserved at 'Bras spungs has a second colophon stating that Empress Bulughan had commissioned the reprint of 200 copies and distributed them to monastic colleges:

The noble Queen known as dPal mo gan endowed with all the heavenly qualities, commissioned two hundred sets of the Rigs gter and offered them [to the monasteries] for teaching and learning, by virtue of which may the Ruler properly enjoy longevity; and may everyone attain Buddhahood. May this be auspicious!' it is recorded.

The colophon appears to be a later addition, because the orthography of the single line text, grammar and spelling differ from the text of the original being smaller and closer, lacking the flow of the archaic style of writing. This second colophon is a testimony to the re-printing for the sake of distribution.

The patron of this operation, Empress 'Bol gan alias Bhol gan (Bulughan), was the wife of the Yuan Emperor Temur (Temür Öljeytü) alias Khreng tsung. In the year 1295, AD she was enthroned as the Senior Queen. Devoted to Tibetan Buddhism, she had a special predilection for Tantric traditions. This is 
reflected in the decoration and the statues of the monastery named dBan nying si (Wan ning si, 万宁寺), which she established in the capital city. It seems that Emperor Temur was unable to exercise political rule due to a chronic disease and therefore this queen exercised most of the political authority. In the year 1308 AD, when Emperor Temur passed away and Emperor Wu tsung (Wuzong Külüg Khaan) ascended the throne, her title as the Senior Queen was withdrawn and she was sentenced to be executed after having been banished to a place called Tung an kro'u (Dong'an zhou, 东安州). ${ }^{2}$

The re-print of the Tshad ma rigs gter was part of a wider operation of printing and distribution of texts. In the year 1299 Empress Bulughan also instigated and sponsored the print edition of six sets of scriptures, Mahāyānasūtrālankāra [by Maitreya] when Tishri Lama Grags pa 'od zer (1294-1303) was in charge of propagating the dharma. She had four hundred copies printed and distributed as free offerings to dharma practitioners.

The six scriptures commissioned by Empress Bulughan were written at the Blue Stupa of the Great Palace in Ta'i Tu (Dadu [Beijing]) in the year 1299 AD and printed at the White Stūpa. These are listed as follows:

1. Title: Theg pa chen po'i mdo sde rgyan (Mahāyāna-sūtrālaṃkāra)

2. $\quad$ Title: dBu ma rtsa ba'i 'grel ba tshig gsal (Prasannapadā by Candrakīrti)

3. Title: Chos mngon pa kun las btus pa (Abhidharma-samuccaya by Asanga)

4. Title: $m N g o n$ pa mdzod (Abhidharmakośa) (to date this text has not been retrieved).

5. Title: Tshad ma rnam par nges pa (Pramānaviniścaya)

6. Title: Tshad ma rigs gter (the 'Treasury of the Science of Valid Cognition' by Sa skya Paṇdita mentioned before)

The colophon of the third text states:

This immaculate teaching to gain a discriminative faculty fully to comprehend all phenomena, and showing the means to attain that [skill] through clear exposition of meanings, this Abhidharmasamuccaya or compendium of knowledge comprises the noble teaching by the Bodhisattva Asanga. For the sake of the noble Queen of the Great Dharmarājā of the world, who is endowed with all the signs of heavenly attributes of nobility, adorned with the seven attributes of an ārya (noble one) such as devotion to the dharma, in order that she, the Glorious

2 See 《元史・列传 - 后妃》卷一百一十四, 中华书局, 1974 年版, 第2873页 
'Bol gan, through her pure devotion attain the state of Sugata, and in order that she may help propagate and spread the Buddha dharma, and to uphold the noble dharma through all her cyclic rebirths, this treasure of dharma has been produced to last long in print form. 'Jam dbyangs, the epitome of the virtuous application of all aspects of the Buddha's doctrine, Kun dga' dbang 'phyug, Bhikșu Rin chen 'phel, the noble translator Karanada and Bad ma se na du lag yang nga [?], Samghada and Zam chung etc., all helped to compile this text and the skilled calligrapher Chos skyabs copied the [model] text, which was [then] nicely engraved [on woodblocks] by skilled artisans.

By the great merit arising from this undertaking, may all sentient beings attain Buddhahood. For the period until that is attained, may none be separated from this noble dharma. May the ruler Tha'i hwu, and his consort (dPon mo) with their princes and subjects enjoy longevity. May the empire expand and the realm enjoy peace; and may the rule be according to the dharma at all times. The essence of the meaning of Abhidharma according to the Mahāyāna tradition has been expounded in depth by the teacher Asanga in this text, the edition and its printing were curated by Yon tan rin chen, an upholder of the Tripitaka.

dPon mo Bhol gan, the noble Queen of the [present] ruler, a descendant in the sixth-generation lineage of the mighty Cakravartin Chinggis Khan, ruling the world according to the dharma, is endowed with noble lineage, physical beauty, mighty good fortune and great power. With undivided devotion and faith rooted in an understanding of the virtues of the Triple Gem [Buddha, Dharma and Sangha] during the time when the imperial preceptor Tishri Bla ma Grags pa 'od zer was the head of the dharma, she commissioned the printing of 400 copies each of Mahāyannasūtrālaṃkāra [by Maitreya]; Madhyamakakārikā [by Nāgārjuna]; Abhidharma-samuccaya [by Asanga]; Abhidharmakośa [by Vasubandhu], Pramānaviniścaya, a setting of valid cognition [by Candrakīrti], and Treasury of the Science of Valid Cognition [by Sakya Pandita]. May the merit accruing from offering copies of these texts to the upholders of the Tripitaka, enable the Great King Po hwang tha'i hwu, dPon mo chen mo, the royal off-spring and lineages, enjoy longevity. May peace prevail in the kingdom, and with the flourishing of the Buddha dharma in ten directions, may everyone attain the unsurpassable state of enlightenment. All this was written at the Blue Stūpa of the Great Palace in Ta'i tu (Beijing) on the 15th day of the 7 th lunar month of the Earth Female Sow year and [the printing] was completed at the White Stūpa. May it be auspicious! 
There is an additional text that was part of this printing operation but was not listed: the text called sDom pa gsum gyi rab dbye ba [a detailed analysis of the three vows] by Sa skya Pandita. According to the colophon this was commissioned by Queen Bhol gan alias 'Bol gan [Bulughan] and, like the other texts, it was completed on the 15th day of the $7^{\text {th }}$ lunar month of the Earth Female Sow year (1299 AD) at the blue Stūpa of Ta'i tu Great Palace, and printed at the White Stūpa. This text is preserved in sNye mo bye mkhar monastery in Central Tibet (and not like the others in 'Bras spungs monastery in lHa sa). The colophon is as follows:

In the Land of Snows, prophesied by the Victorious One (Buddha), with encyclopaedic knowledge of all Buddha's doctrines, the Second Victorious One, the Glorious Sa skya pa [Kun dga' rgyal mtshan] gave this excellent teaching. This noble text that is an exposition of the mind of the enlightened ones [was printed] for the sake of the noble Queen of the Great Dharma Raja of the world, who is endowed with the seven attributes, such as [high ranking] lineage and is adorned with the seven attributes of an ārya such as devotion to the Dharma. Thanks to her devotion, the Great Queen Bhol gan has commissioned the writing and engraving for printing of the stainless commentaries of the Tathāgatas. At this very time, this immaculate teaching of Chos rje [Sa skya Paṇitita] was also being completed successfully. May the accruing merits enable [her] to attain enlightenment. Contemporaneously, in this life, may the Lord Emperor and all his lineage, enjoy longevity and good health, and may all conflicts and harmful elements subside, so that peace and wellbeing spread in all directions. On the 15th day of the 7 th lunar month of the Earth Female Sow year, this was written at the Blue Stūpa of the Ta'i tu (Beijing) Palace, and printed at the White Stūpa. May it be auspicious.

A possible reason for the omission of this text from the list is that it was not originally planned as part of the same printing operation. However, it can be inferred from the colophon that this was an addition to the other scriptures.

These extant prints bear witness to the largest volume of printing scriptures in Tibetan language during the Yuan dynastic period. They also establish Empress Bulughan as the most generous patron of printing in the Tibetan language. The texts were distributed on the 15 th day of the 7 th lunar month of the Earth Female Sow year, which corresponds to the Christian era of 1299 AD. Obviously this was the ceremonial start of a wider distribution. All these texts printed thanks to the endeavor of this Mongolian Empress who was profoundly dedicated to Tibetan Buddhism made it to Central Tibet and 
eventually reached 'Bras spungs and sNye mo bye mkhar monasteries (and probably other Tibetan monasteries, too).

\section{$5 \quad$ Conclusion}

Newly retrieved texts from Central Tibet that were printed at the Yuan court bear witness to the importance given by Mongolian rulers to the multiplication and distribution of Buddhist texts. The colophons celebrating Chabi, Kököchin and Bulughan provide us with precious evidence on the role women played in this process. Bulughan in particular seems to have been much more significant in this respect than any of the known patrons and her contribution is not only remarkable in terms of printing but also actual distribution. It is hoped that more witnesses of a book history that connects different people, Chinese, Mongols and Tibetan in the name of a shared book history will surface and cast light on this momentous process.

\section{References}

Rossabi, M. 1979. "Khublai Khan and the Women in his Family". In Festschrift fuer Herbert Franke, Studia Sino-Mongolica, edited by W. Bauer, 153-180. Wiesbaden: Franz-Steiner Verlag. 1988. Khublai Khan: His Life and Time. Oakland: University of California Press.

Kawa Sherab Sangpo. 2013. "Analysis of Tibetan Language Printings Produced During the Yuan Period (hor spar ma)." Inner Asia 15, 2: 201-224.

2009. "Zangwen <Yuanban> Kao" (Investigating Tibetan Language Blockprints). Zhonguo zangxue 1: 41-50.

Van der Kujip, L. 1993. "Two Mongol Xylographs (hor par ma) of the Tibetan Text of Sa skya Pandita's Work on Buddhist Logic and Epistemology." Journal of the International Association for Buddhist Studies 16: 279-298.

_ 2014. "A Note on hor-par-ma Mongol Xylograph of the Tibetan translation of Dharmakītti's Pramāṇavarttika (Tshad ma rnam 'grel)." http//:www.academia.edu/ $8089475 /$. 